\author{
EWA SZEWCZYK \\ University of Zielona Góra \\ ewa@szewczyk.poznan.pl \\ ORCID ID: 0000-0002-2980-6564
}

\title{
ARTIFICIAL INTELLIGENCE IN ADMINISTRATIVE LAW AND PROCEDURE
}

\section{INTRODUCTION}

Since J. McCarthy used the term 'artificial intelligence' (AI) in the 1950s, it has become a key concept in the technological development of all mankind. It has appeared in every area of life and science. AI has become established in areas of life that were previously thought to be reserved for decision-making by human beings. Artificial intelligence is based on the analysis of large volumes of data, used in algorithms. According to the modern definition, artificial intelligence encompasses the area of knowledge that includes fuzzy logic, evolutionary computation, neural networks, artificial life, and robotics, and one of its essential features is the ability to learn ${ }^{1}$ and take into account new circumstances when solving a given problem ${ }^{2}$. In other words, artificial intelligence is the ability of a machine to mimic or imitate human intelligence ${ }^{3}$.

Algorithms are nothing new. They have been used in computer programmes for decades. Today, however, advanced algorithms have become digital robots - often sophisticated computer programmes (rather than physical entities) with the ability to adapt and 'learn'. However, there is no denying that the unhindered development of AI technologies is marred with public concern and is by no means universally embraced, even though the Covid-19 pandemic has

1 https://www.parp.gov.pl/component/content/article/63599:sztuczna-inteligencja-wlascicielem-praw-do-utworu-badz-wynalazku

2 Zalewski, T. (2020). “Definicja sztucznej inteligencji," Prawo sztucznej inteligencji, L. Lai, M. Świerczyński (eds.), C. H. Beck, p. 2.

3 Zalewski, T. (2020). “Definicja sztucznej inteligencji," Prawo sztucznej inteligencji, C. H. Beck, p. 14. 
boosted acceptance of innovative technologies ${ }^{4}$. Nowadays, the reality from science-fiction films, as never before, requires in-depth reflection, including legal reflection, because in recent years the term 'artificial intelligence - AI' has begun to be used on a large scale in legal sciences.

AI's entry into the domain of culture and the arts has raised several questions around intellectual property rights. AI's creation of a screenplay for a film has raised the question of who owns the copyright to a work authored by AI. According to Polish legislation, only the originator of the work may be the owner of the copyright ${ }^{5}$. From which it is inferred that copyright should be vested in natural persons. This in turn leads to the conclusion that copyright should not be held by the computer software "behind" the creation of a work. Moreover, it is also not clear whether works created by AI should be classified as copyrightable works or as works associated with neighbouring rights. There are more similar examples from everyday life. It may be a matter of controversy, for example, whether a $3 \mathrm{D}$ printer which independently modifies or improves printings can be considered a co-author.

A similar problem can be found in criminal law, where the issue of liability for acts committed by robots has been under discussion for some time. However, also in this area of law it is believed that only a natural person should be held criminally responsible for a criminal act. Against the background of an accident caused by an autonomous vehicle, though, the question has arisen whether a machine can commit a crime and whether fault can be attributed to it. The issue of civil liability for damages caused by AI raises similar questions. A yet different kind of doubt arises in the context of Article 22 of the Regulation (EU) 2016/679 of the European Parliament and of the Council of 27 April 2016 (GDPR), which provides for automated decision-making in individual cases, including so-called 'profiling', if such decision is necessary for the conclusion or performance of a contract between the data subject and the data controller. However, the controller should implement appropriate measures to protect the rights, freedoms and interests of the

4 Hawking, S. Believed that the development of AI would mark the end of the human race - C. Coglianese, D. Lehr, Regulating by Robot: Administrative Decision Making in the MachineLearning Era, p. 1150-1151. https://scholarship.law.upenn.edu/cgi/viewcontent.cgi?article $=2736 \&$ context $=$ faculty_scholarship

5 Article 8 of the Act of 4 February 1994 on Copyright and Neighbouring Rights, consolidated text: Journal of Laws 2019 item 1231, as amended. 
data subject. This means that the controller is obliged to ensure that the data subject can review their data, and therefore has the right to obtain 'human intervention' from the controller, including access to the rules of the algorithm in a given case. This in turn may result, in some cases, in the one who manages the AI not being able to benefit from the results of its work. In this context, it is emphasised that personal data should undoubtedly be processed in a manner which respects human dignity. Therefore, the focus should be on the human beings who create and influence the technology, not on the technology itself. Furthermore, the protection of dignity involves preventing people from being subjected to artificial intelligence systems without their knowledge and consent ${ }^{6}$.

\section{EU DRAFT REGULATION ON ARTIFICIAL INTELLIGENCE}

A significant step towards regulation on AI was the publication by the European Commission on 21 April 2021 of a draft regulation on artificial intelligence. This document, once it becomes law, will have a significant impact on shaping the practice of producing and using artificial intelligence.

The EU legislator in the discussed draft has proposed a definition of artificial intelligence understood as software that can generate results that affect the environments with which it interacts. This can range from standard software combined with AI to logic - or knowledge-based techniques, as well as expert and statistical systems ${ }^{7}$.

In designing the new regulations, the European Commission has adopted a risk-based approach. The assumption that emerges from the proposed solutions is "the greater the AI-related risk, the stricter the regulation". It is not artificial intelligence systems that are regulated, but the way in which they are used. They are divided into 4 categories, corresponding to the level of risk posed by the way they are used. The following

6 https://www.filipiakbabicz.com/nowe-media-i-technologie/2021/04/15/czy-sztuczna-inteligencja-zagraza-prawom-czlowieka/

https://www.twobirds.com/pl/news/articles/2021/poland/210427-alert-prawny-sztuczna-inteligencja 
levels were distinguished: minimal or zero risk, limited risk, high risk and unacceptable risk. A new supervisory body, the European Artificial Intelligence Council, is envisaged. Its tasks will include pooling expertise and disseminating knowledge among the Member States.

\section{Strategic ElEMENTS OF THE ALgORITHM}

The use of AI in a particular area of life, for example in the administration of justice or in public administration, obviously requires the development of an appropriate algorithm. For its proper functioning, the data it can handle plays a special role. Therefore, a crucial issue is that of 'algorithmic bias'. To avoid algorithmic bias, the data should not only be correct, but also diverse. Although the data appears to be objective, it can easily be manipulated and may be biased to reflect cultural, gender, national or other prejudices and preferences.

On the other hand, the issue of transparency of operations and designing the algorithm in such a way that it is possible to trace how the AI makes a decision at each stage preceding it is important. The work of algorithms is sometimes reduced to a black box effect which makes it difficult to find out how the algorithm determined the final result. In the context of the opacity of AI activities, hazards are perceived in the sphere of the right to a fair trial. This is because it requires the reproduction of all the reasoning patterns used by the $\mathrm{AI}$ in a given case. What is required, therefore, is transparency of action, making it possible to explain on the basis of which data and assumptions a particular decision has been taken.

\section{The essence of AI AND ITS ADVANTAges}

The essence of AI is to automate various processes and make decisions based on an algorithm that processes large volumes of data. These activities have so far mostly been carried out by a human being/public servant/officer. 
This is not without an impact on human rights, if only because it creates a strong need to share as well as to protect data.

The positive aspects of the application of AI include the reduction of operating costs and the elimination of errors or abuses committed by humans, if only due to subjectivity ${ }^{8}$. The decisions issued by AI are seen as more balanced and fairer ${ }^{9}$.By applying AI in the decision-making process, timeliness is improved. The foreign literature emphasizes that by applying AI in modern administrative procedure, it can significantly approach two of its core values: justice and efficiency ${ }^{10}$.

\section{AI IN ADMINISTRATIVE LAW AROUND THE WORLD}

As already mentioned, AI has arrived in many areas of life and science. For example, Canadian administrative agencies have long used algorithm-based decision-making tools. The same is the case in the U.S., where in Chicago, for example, sanitation officials are using the Smart Data Platform to help them determine the order of restaurant inspections. And in New York City, the Mayor's Office of Data Analytics uses new technology to work with the city's fire department to show where to send building inspectors ${ }^{11}$. Incidentally, the author of this paper had personally experienced the automation of the decision to grant her tourist visa to Australia already back in 2009. The whole process from the moment she filled in the visa form to the decision on granting her visa took 20 seconds. However, administrative law and procedure regulations themselves have so far made little reference to $\mathrm{AI}^{12}$.

8 Sourdin, T. (2021). Judges, Technology and Artificial Intelligence. The Artificial Judge, Edward Elgar Publishing Limited, p. $86 \mathrm{ff}$.

9 Coglianese, C., Lehr, D. Regulating by Robot: Administrative Decision Making in the MachineLearning Era, pp. 1147-1148. https://scholarship.law.upenn.edu/cgi/viewcontent.cgi?article $=2736 \&$ context $=$ faculty_scholarship

10 Wang, Z. "Reconstruction of the Theory of Administrative Rule of Law in the Era of Artificial Intelligence," Advances in Social Science, Education and Humanities Research (ASSEHR), Volume 252, p. 751.

11 Coglianese, C., Lehr, D. Regulating by Robot: Administrative Decision Making in the MachineLearning Era, p. 1161. https://scholarship.law.upenn.edu/cgi/viewcontent.cgi?article=2736\&context=faculty_scholarship

12 Raso, J. AI and Administrative Law, https://papers.ssrn.com/sol3/papers.cfm?abstract_ $\mathrm{id}=3734656$ 


\section{AI in ADMinistrative PROCEDURE AROUND THE WORLD}

It is recognised in the doctrine of other countries that currently individual societies are moving from the era of industrialism based on the rule of law to the era of digitalisation based on algorithms. In the administrative sphere, the term 'automated decision-making (ADM)' has come into use ${ }^{13}$.

In the legislation of other countries, one can find examples of regulations which show that legislators have standardised automatic issuance of administrative decisions, and therefore the automatic decision-making process. For example, Article 28 of the Swedish Administrative Procedure Act 2017 (2017: 900) stipulates that an administrative decision may be made by an official, a group of officials, or automatically. The latter is taken without the participation of a human being ${ }^{14}$. This is how, for example, the individual risk calculation for taking out a loan is assessed. AI is also used to assess the validity of compensation claims against airline companies for changes due to delayed or cancelled flights. In turn, the Swedes use an AI system called EXOPLORE which analyses the way children read and their eye movements when reading text from a screen in order to detect dyslexia ${ }^{15}$. Although some disadvantages of this way of issuing decisions are recognised, such as the lack of clear and transparent documentation illustrating the process, it is emphasized that it is efficient and effective ${ }^{16}$.

An analogous solution is found in the Hungarian Code of General Administrative Procedure which entered into force on 2 January $2018^{17}$. Article 39 of this Code provides that "the application shall be adjudicated in an automatic decision-making procedure, a summary procedure or a full procedure"18. In turn, Article 40 of the Hungarian Code of General Administrative

13 Suksi, M. (2021). Administrative due process when using automated decision making in public administration: some notes from a Finnish perspective. Introduction. https://link.springer. com/article/10.1007/s10506.020.09269-x

14 https://algorithmwatch.org/en/automating-society-2019/sweden/

15 https://algorithmwatch.org/en/automating-society-2019/sweden/

16 https://www.riksrevisionen.se/download/18.78abb6c61764bda823b5a3a1/160.829.1082190/ RiR_2020_22_en-GB.pdf

17 http://www.coceal.it/pdf/Hungary

18 See more on Hungarian administrative decision-making procedures in: A. Patyi, "Hungary", Administrative Proceedings in the Habsburg Succession Countries, Łódź-Warsaw 2021, p. 144. 
Procedure stipulates that "Automatic decision-making shall apply if a) it is permitted by an Act or government decree, b) all data is available to the authority at the time of the submission of the application, c) decision-making does not require deliberation, and d) there is no party with opposing interests". The above provision requires that four conditions be met for the decision to be issued under the automatic procedure. One is that the case should not involve parties with opposing interests. This means that the method of automatic decision-making can be used in cases involving a single party. Moreover, it may be used if such a possibility is provided for in the law, and if already at the moment of submitting the application the administration body has all the data necessary to make a decision which does not require complicated considerations. Furthermore, according to Article 104(6) of the Hungarian Code, an administrative authority may decide ex officio to issue a decision under the automatic procedure if the decision-making does not involve complex activities ("Where the decision does not require deliberation, the authority may also carry out an ex officio procedure in the framework of automatic decision-making"). In turn, Article 42 of the Hungarian Code of General Administrative Procedure stipulates: "If no appeal lies against a decision made in an automatic decision-making procedure or summary procedure, the party may request the authority, within five days following the communication of the decision, to reconsider his application in a full procedure". Thus, the Hungarian legislator has replaced the missing lack of possibility to appeal against a decision issued in such a manner with the request to resolve the application in a full procedure. This request is limited by a relatively short time limit of 5 days. An automatic decision in accordance with Article 50 of the Hungarian Code of General Administrative Procedure shall be issued within 24 hours. In turn, pursuant to Article 51(c) of the said Act, an administrative body that unreasonably fails to apply the provisions on automatic issuance of decisions in a given case is subject to a financial penalty. 


\section{AI in Polish Administrative LAW AND PROCEEDINGS}

The application of artificial intelligence is designed to automate procedure activities in routine and repetitive cases. Undoubtedly, therefore, it can apply to inherently uncomplicated cases with a simple factual and legal background. Thus, in those cases where it is not beyond the capabilities of an automated system to make certain determinations.

So far, Polish lawmaker has not introduced general regulations corresponding to the Hungarian or Swedish norms on automatic issuance of decisions in certain types of cases. However, the use of the ADM system in cases related to imposing traffic penalties may be noticed. In Poland, the nationwide radar system CANARD (Centre for Automatic Traffic Supervision) has been in operation since 2015. It is linked to an IT system that uses image analysis algorithms to read license plates before automatically imposing fines on speeding drivers ${ }^{19}$.

In addition, certain stages of an administrative procedure conducted entirely in the traditional manner may be automated. An example of this is the automated re-use of biometric data in the form of fingerprints for visa applications, where the applicant has applied for a Schengen visa in the last 59 months and his/her fingerprints were taken previously. Then he/she does not have to submit them again. They will be reused in the proceedings to apply for another visa. In such cases, the computer system will automatically transfer such data to the new case file ${ }^{20}$.

One of the recent changes introduced by the Polish legislator to the construction law concerns the digitalisation of the construction project implementation process to a greater extent than before. The changes made to the Construction Law and the Geodetic and Cartographic Law and several other acts now make it possible to remotely initiate administrative proceedings by filling out the form available online at https://e-budownictwo.gunb.gov.pl/ in one of many situations such as: legalisation proceedings, notification of construction works, or notification of demolition. The changes introduced are part of a wider process aimed at using more complementary registers and

9 https://algorithmwatch.org/en/automating-society-2019/poland/

20 https://www.gov.pl/web/turcja/wizy-informacje-ogolne; accessed on 5 June 2021. 
inventories, such as the Central Building Emissions Register. The introduced solutions will undoubtedly contribute to streamlining the construction process, as well as provide other beneficial effects, e.g. safe archiving of data related to the process (application for a construction permit, construction design, decision on the construction permit, etc.) and their accessibility to officials, building owners and other parties to the proceedings. It should be emphasized, however, that the proceedings in construction project matters is conducted in a traditional manner. The improvement consists only in the possibility to submit electronically the requests that initiate administrative proceedings in a given case.

Another example of the use of AI in administrative matters is the use of the "Unified Anti-Plagiarism System" at all higher education institutions from 1 January 2019 on the basis of Article 76(4) of the Act of 20 July 2018 Law on Higher Education and Science ${ }^{21}$. The provision cited above provides: "where the diploma thesis is a written paper, it shall be checked by a higher education institution prior to the diploma examination with the use of the Unified Anti-Plagiarism System referred to in Article 351 section 1". It makes it possible to check whether the bachelor's or master's thesis submitted by a student is free of plagiarism. A positive result of such a check is a condition for the student to be admitted to further activities in the procedure related to obtaining a higher education diploma. In accordance with Article 351 section 1 of the said Act, the Unified Anti-Plagiarism System shall be maintained by the minister responsible for higher education and science. Under the same Act, other IT systems, such as the POL-on system or the repository of written diploma theses, are also used. They are listed in the provisions of Chapter X of the Law on Higher Education and Science, which includes Articles 242-258.

It should be noted that the institution of service of letters in the Polish administrative proceedings has recently taken a predominantly electronic form. As a result, as of 1 July 2021 electronic delivery is the primary channel of correspondence between private entities (parties to administrative proceedings) and public entities (public administration bodies) ${ }^{22}$. Individuals who will not yet be ready to exchange correspondence electronically, thanks to the hybrid service will be able to receive a traditional letter, consisting in that a letter in

21 Consolidated text: Journal of Laws 2021 item 478, as amended.

22 Act of 18 November 2020 on Electronic Delivery of Letters, Journal of Laws 2020 item 2320. 
an electronic form will be directed to a post office, where it will be printed out (obviously under conditions of confidentiality) and delivered to the addressee in paper form. As a result, the 'digitally excluded' will still be able to send their correspondence to public administration bodies in the traditional (paper) form, and the content of letters sent by these bodies will reach these addressees via the post office by converting electronic content into the paper one. However, if we assume that the use of artificial intelligence should be equated with data processing and the ability to solve problems independently, resulting in a new "product" - e.g., a decision issued automatically or a certificate issued automatically, then the digitalisation of service of letters should not be regarded as AI. Even in those situations where a digitally produced document is served by traditional means. The mere conversion of a "readymade" electronic letter into a paper form is a simple operation that does not require advanced technological processes.

Moreover, it is conceivable that artificial intelligence could find application in the mode regulated in Section VII of the Code of Administrative Procedure - "Issuance of Certificates", Articles 217-22023. This procedure is simplified by its very nature. A certificate is not an administrative decision. It does not create new legal relations, nor does it settle the rights or obligations of citizens. A public administration body issues a certificate if there is a need to ascertain a specific factual or legal state on the basis of the data in its possession. It confirms the factual or legal situation existing on the date of its issuance ${ }^{24}$. Often it is an excerpt from certain documents (e.g., an excerpt from a civil status certificate), or a copy or certificate, e.g., one issued by the Social Insurance Institution, stating that the applicant is not in arrears with contributions. It can therefore be assumed that the steps taken to issue the certificate are largely routine and could successfully take place in automated proceedings. So far, however, the Polish legislator has failed to recognise the potential of AI in the discussed procedure.

Of course, the application of AI in administrative law and proceedings can involve not only actually making a decision, but also recommending a decision to the official who will be ultimately in charge with making it.

23 Act of 14 June 1960, consolidated text: Journal of Laws 2021 item 735, as amended.

24 Ochendowski, E. (2012)Postępowanie administracyjne, ogólne, egzekucyjne i sądowoadministracyjne. Wybór orzecznictwa. Toruń, pp. 245-246. 
In addition, artificial intelligence can draft preliminary assessments as to the legal or factual status of a case. The extent to which it can be applied should depend on the legal framework adopted in the country concerned.

\section{Recommendations of the European Parliament}

The Resolution of the European Parliament of 20 January 2021 making recommendations to the Commission on artificial intelligence (2020/2013/ INI) shows that the use of AI-assisted systems in the decision-making process of public authorities should be subject to strict criteria of control, inter alia, in terms of transparency, non-discrimination, security and social responsibility, in order to avoid biased decisions unfavourable to citizens. The decisions should be taken under human supervision. And they should be contestable. Artificial intelligence, robotics and other similar related technologies must not conflict with fundamental rights and the principles of democracy and the rule of law. ${ }^{25}$

\section{Conclusion}

The development of information/digital technologies over the last decades, which has entered all fields of human activity, suggests that it is also inevitable in the field of legal sciences, and one may speculate that it is going to continue. For obvious reasons, the ever-increasing volume of data leads to automation of the processes involved. Therefore, it should be expected that also in Polish administrative proceedings the legislator will introduce framework norms concerning automatic issuance of decisions in some administrative cases. The experience of other countries in this regard indicates that, bearing in mind the procedural fairness that should be the hallmark of any decision-making mode, including the automatic decision-making (ADM) mode, it must not be forgotten that it is ultimately the human being who is responsible for the inputs and outputs that AI will use in a particular administrative case.

\footnotetext{
25 https://www.europarl.europa.eu/doceo/document/TA-9-2021-0009_PL.html
} 